\title{
The similarity and difference in the flora of the pine forest on the southern border of the range of Pinus sylvestris L.
}

\author{
Nataliya $\mathrm{Kin}^{*}$ \\ Institute of Steppe of the Ural Branch of the Russian Academy of Sciences, 460000, Pionerskaya Str., \\ 11, Orenburg, Russia
}

\begin{abstract}
The data of studies and calculations showing the high floristic similarity of the pine forests of the Russian Plain located in the southern part of Pinus sylvestris L. area. Especially high similarity is observed in the indigenous fraction of the flora. The similarity of floras in the adventive fraction is insignificant. Taking into account the forecast of a possible, in the near future, floristic homogenization due to the species of the adventive fraction, we calculated an estimation index, which indicates an opposite process of homogenization - differentiation. Given the division of advents into groups according to the introduction time, we calculated the estimated index separately for archaeophytes and kenophytes. It was revealed that in pairs of pine forests located relatively close to each other, archaeophytes enhance differentiation, and kenophytes enhance the homogenization of flora. Differential taxa (families, genera, and species) are found only in one of all the studied pine forests, that determine the characteristics of the studied floras. Endemic species have been established that give originality to the flora of the studied pine forests.
\end{abstract}

\section{Introduction}

Pine forests, on the southern limit of Pinus sylvestris, are widespread in the steppe and forest-steppe zones. The edge areal location of the pine forests makes them the most dynamic and sensitive to environmental changes, which is primarily reflected in the composition and development of the flora. Florogenesis historically had an aborigen basis [2], but at present, alien elements - adventiv species — are exerting a growing influence on this process. According to forecasts made regarding adventiv species of the flora of the Central Black Earth Region of Russia, [3] percentage of this fraction will steadily increase. This is facilitated by climate change, increased anthropogenic transformation of landscapes and, as a result, the formation of derived landscapes with altered zonal communities. The amount of adventiv species in flora increases phyto-diversity $[4,5]$, but over time, the resettlement of some species may lead to increase similarity between floras. This phenomenon is called "biotic homogenization" [4, 6], "unification of flora" [3, 7]. Adventiv

\footnotetext{
* Corresponding author: kin_no@mail.ru
} 
species, increasing their ranges, can negatively affect the ranges of indigenous, mostly rare and endemic species, in the direction of their reduction $[8,9,10]$.

On the contrary, the same climatic features, characterized by sharp fluctuations in the conditions of a subarid climate, the difference in the historical and geological processes of the formation of territories, the features of anthropogenic impact can limit some and catalyze the penetration of other adventiv species. This process, the opposite of homogenization, is called differentiation.

\section{Materials and methods}

In order to identify floristic similarities and differences, to establish the peculiarities of florogenesis due to the adventive fraction of the flora, we studied the pine forest flora of the Russian Plain: Usmansky (an area of 70700 hectares, 31053 hectares natural reserve) and Khrenovsky (40210 hectares) located in the forest-steppe subzone of the Oka-Don lowland [11], Buzuluksky (106788 hectares, 14399 hectares - the protection zone) and Krasnosamarsky (13554 hectares), located in the steppe zone of the Volga region [12].

The Jaccard coefficient was used to identify the similarity of pine forest flora $\left(\mathrm{K}_{\mathrm{J}}\right): \backslash$

$$
K_{J}=\frac{C}{A+B-C}
$$

$\mathrm{C}$ is the number of species for a pair of compared pine forests; $\mathrm{A}$ - the number of species in the flora of one comparable pine forest; B - the number of species in the flora of another comparable pine forest.

If the coefficient $K_{\mathrm{J}}$ exceeds 0.5 , then more than half of the species in the flora of the studied pine forests are common and indicates a high similarity of the compared flora.

The Jaccard coefficient was calculated both for the pine forests flora as a whole and separately for indigenous $\left(\mathrm{K}_{\mathrm{Jind}}\right)$ and adventive $\left(\mathrm{K}_{\mathrm{Jadv}}\right)$ species, dividing the latter into archaeophytes $\left(\mathrm{K}_{\mathrm{Jarch}}\right)$ and kenophytes $\left(\mathrm{K}_{\mathrm{Jken}}\right)$.

To identify the role of species of the adventive fraction in the process of homogenization or differentiation at this stage of the development of pine forests flora, an estimated index is calculated. The estimated index $(\mathrm{H})$ is expressed through the difference the Jaccard coefficients calculated for the floras of the studied pine forests with the participation the adventive species $\left(\mathrm{K}_{\mathrm{J}}\right)$ and the indigenous component of the flora $\left(\mathrm{K}_{\mathrm{Jind}}\right)$ :

$$
H=K_{J}-K_{\text {Jind }}
$$

A positive result indicates homogenization, and a negative indicates differentiation of the floras [4].

Considering that advents have a temporary gradation (archaeophytes and kenophytes), it is worthwhile to find out due at the expense a group this or that process dominates. For this purpose, the estimated index for archaeophytes $\left(\mathrm{H}_{\text {arch }}\right)$ and kenophytes $\left(\mathrm{H}_{\mathrm{ken}}\right)$ was calculated:

$$
\begin{aligned}
& H_{\text {arch }}=K_{J a d v}-K_{J a r c h} \\
& H_{k e n}=K_{J a d v}-K_{J k e n}
\end{aligned}
$$

a positive result indicates homogenization, and a negative one indicates differentiation of flora.

\section{Results}


The results of calculating the similarity of floras by the Jaccard coefficient, their indigenous and adventive of fractions are given in the table 1.

Table 1. The similarity of the flora of pine forests in the Jaccard coefficient

\begin{tabular}{|c|c|c|c|c|c|c|c|}
\hline \multirow[t]{2}{*}{ Pine forests } & \multicolumn{2}{|c|}{ Usmansky } & \multicolumn{2}{|c|}{ Khrenovsky } & \multicolumn{2}{|c|}{ Buzuluksky } & Krasnosamarsky \\
\hline & \multicolumn{7}{|c|}{$K_{\text {Jadv. }}$} \\
\hline Usmansky & \multicolumn{2}{|c|}{-} & \multicolumn{2}{|c|}{0,4} & \multicolumn{2}{|c|}{0,28} & 0,24 \\
\hline Khrenovsky & 0,60 & 0,65 & \multicolumn{2}{|c|}{ 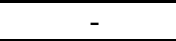 } & \multicolumn{2}{|c|}{0,32} & 0,33 \\
\hline Buzuluksky & 0,52 & 0,54 & 0,55 & 0,55 & \multicolumn{2}{|c|}{-} & 0,49 \\
\hline \multirow[t]{2}{*}{ Krasnosamarsky } & 0,43 & 0,45 & 0,49 & 0,47 & 0,52 & 0,53 & - \\
\hline & $\mathrm{K}_{\mathrm{J}}$ & $K_{\text {Jind. }}$ & $\mathrm{KJ}_{\mathrm{J}}$ & $\mathrm{K}_{\text {Jind. }}$ & $K_{J}$ & $K_{\text {Jind. }}$ & \\
\hline
\end{tabular}

The greatest similarity of flora was found in the Usmansky and Khrenovsky pine forests located in the same natural subzone and geographically close to each other $95 \mathrm{~km}$ The similarity in the indigenous fractions of the flora of these forests is especially high - 0.65. A sufficiently high floristic affinity was revealed near Buzuluksky pine forest with all the other pine forests under consideration, both in general for the flora and its indigenous fraction. The high similarity of the Buzuluksky pine forest flora with other pine forests is probably associated with a significant variety of landscapes, ecosystems, unique habitats, which within this object provides a high floristic diversity of the territory, and, as a result, increases the similarity with other pine forests. In addition, the Buzuluksky and Krasnosamarsky pine forests are connected by a narrow strip of forest along the right bank of the Samara river [13] and are located in the steppe zone of the Volga region.

In the adventiv fraction of the flora of the studied pine forests, the similarity is small. The closest adventiv fractions of the flora of the Buzuluksky and Krasnosamarsky, as well as the Usmansky and Khrenovsky pine forests, which is explained by the proximity of the location of these pairs of forest areas.

The estimated index (table 2) for each pair of compared pine forests has a negative value, which indicates the process of differentiation, with the exception of the pair Buzuluksky - Khrenovsky forests.

Table 2. Estimated indices of the flora of the studied burs and their adventiv fractions

\begin{tabular}{|c|c|c|c|c|}
\hline The compared pine forests & $\begin{array}{c}\text { The distance between } \\
\text { the pine forests, } \mathbf{~ k m}\end{array}$ & $\mathbf{H}$ & $\mathbf{H}_{\text {arch }}$ & $\mathbf{H}_{\text {ken }}$ \\
\hline Krasnosamarsky - Buzuluksky & 75 & -0.01 & -0.174 & 0.109 \\
\hline Khrenovsky - Usmansky & 95 & -0.05 & -0.176 & 0.042 \\
\hline Krasnosamarsky - Khrenovsky & 768 & -0.02 & 0.045 & 0.095 \\
\hline Krasnosamarsky - Usmansky & 789 & -0.02 & -0.389 & -0.571 \\
\hline Buzuluksky - Khrenovsky & 840 & 0.00 & -0.123 & 0.095 \\
\hline Buzuluksky - Usmansky & 865 & -0.02 & 0.053 & 0.065 \\
\hline
\end{tabular}

The data obtained are consistent with the conclusions made by O.V. Morozova [4] that the greater the distance between the flora, the less differentiation. So, the relatively closely located forests Khrenovsky and Usmansky have the highest differentiation among all the studied forests. The remaining pairs of forests are at a considerable distance from each other. In this case, the homogenization coefficient increases, and the differentiation decreases. The exception is a pair of Buzuluksky - Krasnosamarsky pine forests. They are closely located $(75 \mathrm{~km})$, but are characterized by less differentiation of flora than the rest, located at a greater distance from each other. Perhaps this is due to the fact that the Krasnosamarsky and Buzuluksky forests in the past constituted a single massif.

Calculations showed that in pairs of pine forests located relatively close to each other due to archaeophytes differentiation occurs, and due to kenophytes - homogenization of the 
flora (table 2). In the Krasnosamarsky and Khrenovsky pine forests, as well as in the Buzuluksky and Usmansky, both temporary groups of adventivs are involved in the process of homogenization. This is probably due to the type of use of these forests. Khrenovsky and Krasnosamarsky pine forests do not have a high conservation status and are actively used by humans, and the Usmansky and Buzuluksky pine forests are partially or fully federal protected areas. In the Krasnosamarsky-Usmansky pine forests pair, the process of differentiation proceeds both due to archaeophytes and kenophytes.

When comparing the flora of pine forests, differential species, genera, and families were revealed - taxa that reflect the nature of the flora and are found only in one of the compared floras [14]. The data obtained are summarized in table 3. Undoubtedly, the presence of such taxa most clearly emphasizes the peculiarity of the studied floras.

Table 3. Quantitative indicators of the differential species of the studied pine forests

\begin{tabular}{|l|c|c|c|c|}
\hline \multicolumn{1}{|c|}{ The name of pine forests } & $\mathbf{1}$ & $\mathbf{2}$ & $\mathbf{3}$ & $\mathbf{4}$ \\
\hline $\begin{array}{l}\text { Absolute number of differencial species / share (\%) of all } \\
\text { recorded species in the flora }\end{array}$ & $249 / 23.2$ & $47 / 6.0$ & $94 / 12.0$ & $56 / 8.5$ \\
\hline $\begin{array}{l}\text { Aborigens, their absolute number / share (\%) of all } \\
\text { indigenous species recorded in the flora }\end{array}$ & $148 / 17.4$ & $39 / 5.8$ & $72 / 10.7$ & $51 / 8.8$ \\
\hline $\begin{array}{l}\text { Adventivs, their absolute number / share (\%) of all adventiv } \\
\text { species in the flora }\end{array}$ & $89 / 41.8$ & $8 / 7.1$ & $18 / 16.5$ & $4 / 5.1$ \\
$\begin{array}{l}\text { - absolute number of archaeophytes / share (\%) of all } \\
\text { archaeophytes recorded in the flora } \\
\text { - absolute number of kenophytes / share (\%) of all } \\
\text { kenophytes recorded in the flora }\end{array}$ & $11 / 26.8$ & $2 / 6.7$ & $3 / 8.8$ & $0 / 0.0$ \\
\hline $\begin{array}{l}\text { Introducers, their absolute amount / share (\%) of all } \\
\text { introducers in the flora }\end{array}$ & $78 / 45.3$ & $6 / 7.3$ & $15 / 20.0$ & $4 / 8.3$ \\
\hline
\end{tabular}

Pine forest: 1. Usmansky, 2. Khrenovsky, 3. Buzuluksky, 4. Krasnosamarsky.

In the Usmansky pine forest has the largest number of differential species, but only $59.4 \%$ of the aborigines among them. In other studied pine forests the share of indigenous differential species is more significant and makes $76.6 \%$ in Buzuluksky, $82.9 \%$ in Khrenovsky and $91.0 \%$ in Krasnosamarsky pine forests. Correspondingly, the share of differential adventivs species in the Usmansky forest is more significant $(35.7 \%)$, compared with other studied forests, where their percentage of 7.1 is in Krasnosamarsky, 17.0 in Khrenovsky and 19.0 in Buzuluksky. It should be noted that in all pine forests under study, among adventiv differential species, the highest percentage of kenophytes, with a later skidding, compared with archaeophytes.

The flora of the Usmansky pine forest has the largest number of differential taxa. 12 families are noted only in the flora of this forest. Of these, 4 families include exclusively aborigen species: Ericaceae, Oxalidaceae, Elatinaceae, Saxifragaceae, the remaining 8 contain representatives of the adventiv fraction of the flora. In the flora of the Usmansky pine forest, 72 differential genera were registered, among which there were 37 genera from the aborigens, 34 from the adventiv fraction of the flora and 1 genus from introducent. 5 endemic species recorded in the pine forest flora: Euphorbia gmelinii Steud., Psephellus sumensis (Kalen.) Greuter, Stipa anomala P. Smirn s.str., Aconitum nemorosum Bieb. ex Reichenb.

In the flora of Khrenovsky pine forest, the Adoxaceae family is differential. Like Adoxa, the genera Aconogonum, Ononis, Berula are differential for this pine forest. Unlike Usmansky, in the flora of Khrenovsky forest no differential families and genera from the adventitious fraction of the flora were revealed. Originality of the flora of Khrenovsky pine forest is given by 4 endemic species: Centaurea pineticola Iljin, Centaurea sophiae Klokov., Iris pineticola Klokov., Festuca wolgensis P.A. Smirn. 
In the flora of the Buzuluky pine forest, one differential family of Ephedraceae and 8 genera was revealed. Among the latter, 5 contain representatives of the aborigen fraction of pine forest flora. 8 endemic species identified here: Lathyrus litvinovii Iljin, Elytrigia reflexiaristata (Nevski) Nevski, Hylotelephium zhiguliense Tzvelev, Astragalus wolgensis Bunge, Tragopogon tanaiticus Artemcz., Dianthus fischeri Spreng., Myosotis popovii Dobrocz., Chondrilla graminea M. Bieb.

The flora of Krasnosamarsky pine forest differs from others in the presence of the Limoniaceae family and 9 genera that are differential for it. Of these genera, 7 combine the species of the aborigen fraction of the flora. The special nature of the flora of Krasnosamarsky pine forest was expressed in the presence of 2 endemic species: Ferula caspica Bieb. and Allium podolicum (Asch. \& Graebn.) Blocki ex Racib.

\section{Discussion}

The result of the research showed high floristic similarity between the forests of the Russian plain. As flora is represented by two factions, noted that the similarity in of the aborigen faction is much higher than in the adventive fraction of flora. The predictions of scientists about the approaching unification of the flora due to the active adaptation and settlement of alien species was not confirmed to us at this time. This is also indicated by the data obtained in the calculation of the estimated indices of the compared pine forests It was established that kenophytes have a greater effect on homogenization, and archaeophytes on the differentiation of flora. The manifestation of this or that process significantly depends on the presence or absence of the security status of the studied pine forests.

The most striking floristic differences of the studied pine forests were shown due to differential taxa and endemic species.

\section{Acknowledgements}

The work was carried out in the framework of the state task of Institute of Steppe of the Ural Branch of the RAS, theme № AAAA-A17-117012610022-5

\section{References}

1. E.A. Starodubtseva, Vascular plants. Flora of the Voronezh reserve. Vascular plants, bryophytes, lichens, mushrooms. Flora and fauna of reserves. (Moscow, 1999)

2. A.I. Tolmachev, Comparative floristry methods and problems of florogenesis (Novosibirsk, 1986)

3. A.A. Tishkov, Adventive flora of the Voronezh region: Historical, biographic, economic aspects (Voronezh, 2004)

4. O.V. Morozova, Russian Journal of Biological Invasions, 3 (2018)

5. D.F. Sax, S.D. Gaines, Trends in Ecology and Evolution, 18, 11 (2003)

6. M.L. McKinney, J.L. Lockwood, Trends in Ecology and Evolution, 14 (1999)

7. A.A. Tishkov, Anthropocene, Proceedings of the Zoological Museum of Moscow State University, 54 (2016)

8. J.D. Olden, N.L. Poff, Am. Nat., 162 (4) (2003)

9. H. Qian, R.E. Ricklefs, Ecology Letters, 9 (2006) 
10. M. Winter, I. Kühn, F.A. La Sorte, O. Schweiger, W. Nentwig, S. Klotz, Global Ecology and Biogeography (2010)

11. F. N .Milkov, Natural areas of the USSR (Moscow, 1977)

12. Buzuluk Bor. General essay and forest crops, I (Moscow-Leningrad, 1949)

13. E.S. Korchikov, N.V. Prokhorova, T.I. Plaksina, N.M. Matveev, Yu.V. Makarova, A.I. Kozlov, Samara Luka: problems of regional and global ecology. Togliatti, 19, 1 (2010)

14. R.V. Kamelin, Flora of the North of European Russia (in comparison with the neighboring territories) (Saint-Petersbourg, 2017) 